\title{
Monohelical quinquepyridine complexes of rhenium-(I) and -(II)
}

\author{
Paul Kwok-Keung Ho, ${ }^{a}$ Kung-Kai Cheung, ${ }^{a}$ Shie-Ming Peng ${ }^{b}$ and Chi-Ming Che ${ }^{*, a}$ \\ ${ }^{a}$ Department of Chemistry, The University of Hong Kong, Pokfulam Road, Hong Kong
}

${ }^{b}$ Department of Chemistry, National Taiwan University, Taipei, Taiwan

Three $2,2^{\prime}: 6^{\prime}, 2^{\prime \prime}: 6^{\prime \prime}, 2^{\prime \prime \prime}: 6^{\prime \prime \prime}, 2^{\prime \prime \prime \prime}$-quinquepyridine (qpy) complexes of rhenium, $\left[\mathrm{Cl}(\mathrm{OC})_{3} \mathrm{Re}^{\prime}(\mathrm{qpy}) \mathrm{Re}^{\prime}(\mathrm{CO}){ }_{3} \mathrm{Cl}\right] \mathbf{1}$, $\left[(\right.$ py $\left.)(\mathrm{OC})_{3} \operatorname{Re}^{\mathrm{I}}(\mathrm{qpy}) \operatorname{Re}^{\mathrm{I}}(\mathrm{CO})_{3}(\mathrm{py})\right]\left[\mathrm{ClO}_{4}\right]_{2} 2$ (py = pyridine) and $\left[\mathrm{Re}^{\mathrm{III}}(\mathrm{qpy}) \mathrm{Cl}_{2}\right]\left[\mathrm{ClO}_{4}\right]$ 3, have been prepared and their physicochemical properties studied. The crystal structures of $\mathbf{2}$ and $\mathbf{3}$ have been determined: $\mathbf{2}$ is a monohelical bimetallic complex with two fac-tricarbonyl rhenium(I) moieties linked by the qpy ligand and the five pyridyl rings of qpy divide in the fashion bipy-py-bipy (bipy = bipyridine fragment and py $=$ pyridine spacer); 3 is a seven-co-ordinated monohelical rhenium(III) complex with pentagonal-bipyramidal geometry in which the two chloride ligands are trans to each other. Complexes 1 and $\mathbf{2}$ display photoluminescence in the spectral range $560-600 \mathrm{~nm}$. The electrochemical properties of 2 and 3 are discussed.

Rhenium complexes containing pyridine-type ligands have received considerable attention in recent years. Rhenium(I) tricarbonyl complexes containing $\alpha$-diimine ligands have been extensively used for photochemical studies. Their high stability, long excited-state lifetime, high emission quantum yield and the ease of tuning of the physicochemical properties through the variation of peripheral moieties accounts for their versatility. ${ }^{1,2}$ Recent studies by Harman and co-workers ${ }^{3}$ also highlighted the potential applications of rhenium polypyridine complexes in organometallic chemistry. However, there are few examples of rhenium complexes containing long-chain oligopyridines and the recent examples are some seven-co-ordinated oxo- and nitrido-rhenium(v) complexes of $2,2^{\prime}: 6^{\prime}, 2^{\prime \prime}: 6^{\prime \prime}, 2^{\prime \prime \prime}$-quaterpyridine. ${ }^{4}$ Studies by Constable and co-workers ${ }^{5,6}$ showed that polydentate ligands based on oligopyridines spontaneously assemble mono- and bi-nuclear helical complexes upon reactions with $\mathrm{Cu}^{\mathrm{I}}, \mathrm{Cu}^{\mathrm{II}}, \mathrm{Ag}^{1}, \mathrm{Co}^{\mathrm{II}}, \mathrm{Ni}^{\mathrm{II}}$ and $\mathrm{Pd}^{\mathrm{II}}$. Many of these examples were obtained with $2,2^{\prime}: 6^{\prime}, 2^{\prime \prime}: 6^{\prime \prime}, 2^{\prime \prime \prime}: 6^{\prime \prime \prime}, 2^{\prime \prime \prime}$ quinquepyridine (qpy). ${ }^{5}$ Herein we describe the preparation of monohelical bimetallic rhenium(I) and monohelical rhenium(III) complexes of qpy, their crystal structures, electrochemical and photophysical properties.

\section{Experimental}

\section{Materials}

Pentacarbonylrhenium(I) chloride and silver perchlorate monohydrate were obtained from Strem Chemicals, lithium

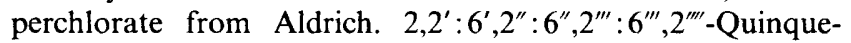
pyridine ${ }^{7}$ and $\left[\mathrm{Re}^{\mathrm{v}} \mathrm{OCl}_{3}\left(\mathrm{PPh}_{3}\right)_{2}\right]^{8}$ were prepared according to the literature procedures. Tetrabutylammonium hexafluorophosphate was obtained from Southern Analytical Chemicals. Acetonitrile (Ajax, AR) was purified by treatment with $\mathrm{KMnO}_{4}$ and then distilled over $\mathrm{CaH}_{2}$. Dichloromethane (Ajax, AR) was purified by washing with concentrated $\mathrm{H}_{2} \mathrm{SO}_{4}$ followed by $5 \%$ aqueous $\mathrm{Na}_{2} \mathrm{CO}_{3}$ solution and then distilled over $\mathrm{CaH}_{2}$. Methanol (Merck, GR) and all the other chemicals and solvents were used as received. All solvents for syntheses were analytical grade.

\section{Measurements}

Proton NMR spectra were obtained on a JEOL 270 Fouriertransform spectrometer with tetramethylsilane as internal reference. Elemental analyses were conducted by Butterworth Laboratories Ltd. Electron impact (EI) and FAB mass spectra were collected on a Finnigan MAT 95 high-resolution spectrometer, as were electrospray mass spectra using acetone as mobile phase. Cyclic voltammetry was performed with a Princeton Applied Research (PAR) model 175 Universal Programmer and model 173 potentiostat-galvanostat. The working electrode was glassy carbon. All measurements were made against $\mathrm{Ag}-\mathrm{AgNO}_{3}\left(0.1 \mathrm{~mol} \mathrm{dm}{ }^{-3}\right.$ in $\left.\mathrm{MeCN}\right)$. The UV/VIS spectra were recorded on a Perkin-Elmer Lambda 19 UV/VIS/NIR spectrophotometer, infrared spectra as Nujol mulls on a Nicolet 20-FXC FT-IR spectrophotometer and steady-state emission spectra on a Spex Fluorolog-2 spectrofluorometer. Emission lifetime measurements were performed with a Quanta Ray DCR-3 Nd-YAG laser system (pulsed output $355 \mathrm{~nm}, 8 \mathrm{~ns}$ ). Solutions for photochemical experiments were degassed by at least four freeze-pump-thaw cycles.

\section{Syntheses}

[Cl(OC) $\left.)_{3} \operatorname{Re}^{\mathrm{I}}(\mathrm{qpy}) \operatorname{Re}^{\mathrm{I}}(\mathrm{CO})_{3} \mathrm{Cl}\right]$ 1. A mixture of $\left[\mathrm{Re}(\mathrm{CO})_{5} \mathrm{Cl}\right]$ $(100 \mathrm{mg}, 0.24 \mathrm{mmol})$ and qpy $(47 \mathrm{~g}, 0.12 \mathrm{mmol})$ in degassed methanol $\left(20 \mathrm{~cm}^{3}\right)$ was heated to reflux under an argon atmosphere for $12 \mathrm{~h}$. The resulting bright yellow suspension was filtered off and washed with cold methanol. The yield was quantitative. The product was recrystallized by diffusion of diethyl ether into dichloromethane solution (Found: C, 37.20; $\mathrm{H}, 1.65$; N, 7.10. Calc. for $\mathrm{C}_{31} \mathrm{H}_{17} \mathrm{Cl}_{2} \mathrm{~N}_{5} \mathrm{O}_{6} \mathrm{Re}_{2}$ : C, 37.30, $\mathrm{H}$, $1.70 ; \mathrm{N}, 7.00 \%$ ). Mass spectrum (FAB): $m / z 999$ (1) and 964 $(1-\mathrm{Cl})$. IR ( $\tilde{\mathrm{v}}_{\mathrm{CO}} / \mathrm{cm}^{-1}$, Nujol mull): 1902 and 2015.

$\left[\left(\right.\right.$ py) $\left.(\mathrm{OC})_{3} \operatorname{Re}^{\mathrm{I}}(\mathrm{qpy}) \operatorname{Re}^{\mathrm{l}}(\mathrm{CO})_{3}(\mathrm{py})\right]\left[\mathrm{ClO}_{4}\right]_{2} 2$ (py = pyridine) A suspension of complex 1 (100 mg, $0.092 \mathrm{mmol}$ ) and $\mathrm{AgClO}_{4}$ (38 $\mathrm{mg}, 0.184 \mathrm{mmol}$ ) in degassed pyridine $\left(5 \mathrm{~cm}^{3}\right)$ was heated to reflux under an argon atmosphere in the dark for $8 \mathrm{~h}$. The resulting greenish yellow solution was filtered through Celite and the volume of the solution was reduced under vacuum. The yellow slurry obtained was purified by chromatography on a $10 \times 300 \mathrm{~mm}$ neutral alumina column and was eluted with a gradient of dichloromethane-acetonitrile. Two kinds of crystal, greenish yellow needles and prisms, were obtained by slow diffusion of diethyl ether into acetonitrile solution. They were found to have the same elemental compositions and absorption and emission properties, but their ${ }^{1} \mathrm{H}$ NMR spectra were different. As discussed, these two crystals are suggested to be two stereoisomers (Found: C, 38.20; H, 2.00; N, 7.65. Calc. for $\mathrm{C}_{41} \mathrm{H}_{27} \mathrm{Cl}_{2} \mathrm{~N}_{7} \mathrm{O}_{14} \mathrm{Re}_{2}$ : C, 38.30; $\left.\mathrm{H}, 2.10 ; \mathrm{N}, 7.65\right) .{ }^{1} \mathrm{H}$ NMR $\left(270 \mathrm{MHz}, \mathrm{CD}_{3} \mathrm{CN},-35^{\circ} \mathrm{C}\right.$, numbering of hydrogens as in Scheme 2): needle form, $\delta 9.20\left(\mathrm{~d}, 1 \mathrm{H}, \mathrm{H}^{\mathrm{E} 3}\right), 8.95\left(\mathrm{~d}, 1 \mathrm{H}, \mathrm{H}^{\mathrm{A} 3}\right)$, 
$8.63\left(\mathrm{~d}, 1 \mathrm{H}, \mathrm{H}^{\mathrm{D} 3 / \mathrm{D} 5}\right), 8.57\left(\mathrm{~d}, 1 \mathrm{H}, \mathrm{H}^{\mathrm{A} 6}\right), 8.49\left(\mathrm{~d}, 1 \mathrm{H}, \mathrm{H}^{\mathrm{D} 3 / \mathrm{D} 5}\right)$, $8.43\left(\mathrm{~d}, 2 \mathrm{H}, \mathrm{H}^{\mathrm{B} 3 / \mathrm{B} 5}\right.$ and $\left.\mathrm{H}^{\mathrm{E} 6}\right), 8.35\left(\mathrm{~m}, 4 \mathrm{H}, \mathrm{H}^{\mathrm{B} 4}, \mathrm{H}^{\mathrm{C} 3 / \mathrm{Cs}}\right.$, $\mathrm{H}^{\mathrm{D} 4}$ and $\left.\mathrm{H}^{\mathrm{E} 5}\right), 8.30\left(\mathrm{t}, 1 \mathrm{H}, \mathrm{H}^{\mathrm{A} 4}\right), 8.10\left(\mathrm{~d}, 1 \mathrm{H}, \mathrm{H}^{\mathrm{B} 3 / \mathrm{B} 5}\right)$, $8.06\left(\mathrm{~d}, 1 \mathrm{H}, \mathrm{H}^{\mathrm{C} 3 / \mathrm{C} 5}\right), 8.01\left(\mathrm{dd}, 1 \mathrm{H}, \mathrm{H}^{\mathrm{C} 4}\right), 7.94\left(\mathrm{~d}, 2 \mathrm{H}, \mathrm{H}^{\mathrm{G} 2}\right)$, $7.85\left(\mathrm{t}, 1 \mathrm{H}, \mathrm{H}^{\mathrm{E} 4}\right), 7.80\left(\mathrm{t}, 1 \mathrm{H}, \mathrm{H}^{\mathrm{F} 4}\right), 7.67\left(\mathrm{~m}, 3 \mathrm{H}, \mathrm{H}^{\mathrm{F} 2}\right.$ and $\left.\mathrm{H}^{\mathrm{A} 5}\right)$, $7.23\left(\mathrm{t}, 2 \mathrm{H}, \mathrm{H}^{\mathrm{F} 3}\right), 7.10\left(\mathrm{t}, 1 \mathrm{H}, \mathrm{H}^{\mathrm{G} 4}\right)$, and $6.69\left(\mathrm{t}, 2 \mathrm{H}, \mathrm{H}^{\mathrm{G} 3}\right)$; prism form, $\delta 9.15\left(\mathrm{~d}, 2 \mathrm{H}, \mathrm{H}^{\mathrm{A} 3}\right.$ and $\left.\mathrm{H}^{\mathrm{E} 3}\right), 8.54\left(\mathrm{~s}, 3 \mathrm{H}, \mathrm{H}^{\mathrm{C} 3}, \mathrm{H}^{\mathrm{C} 4}\right.$ and $\left.\mathrm{H}^{\mathrm{C} 5}\right), 8.43\left(\mathrm{t}, 2 \mathrm{H}, \mathrm{H}^{\mathrm{B} 4}\right.$ and $\left.\mathrm{H}^{\mathrm{D} 4}\right), 8.39\left(\mathrm{~d}, 2 \mathrm{H}, \mathrm{H}^{\mathrm{B} 3 / \mathrm{B} 5}\right.$ and $\left.\mathrm{H}^{\mathrm{D} 3 / \mathrm{D} 5}\right), 8.34\left(\mathrm{~d}, 2 \mathrm{H}, \mathrm{H}^{\mathrm{A} 6}\right.$ and $\left.\mathrm{H}^{\mathrm{E} 6}\right), 8.24\left(\mathrm{t}, 2 \mathrm{H}, \mathrm{H}^{\mathrm{A} 4}\right.$ and $\left.\mathrm{H}^{\mathrm{E} 4}\right)$, $8.23\left(\mathrm{t}, 2 \mathrm{H}, \mathrm{H}^{\mathrm{F} 4}\right.$ and $\left.\mathrm{H}^{\mathrm{G} 4}\right), 7.80\left(\mathrm{~d}, 2 \mathrm{H}, \mathrm{H}^{\mathrm{B} 3 / \mathrm{B} 5}\right.$ and $\left.\mathrm{H}^{\mathrm{D} 3 / \mathrm{D} 5}\right)$, $7.78\left(\mathrm{~d}, 4 \mathrm{H}, \mathrm{H}^{\mathrm{F} 2}\right.$ and $\left.\mathrm{H}^{\mathrm{G} 2}\right), 7.75\left(\mathrm{t}, 2 \mathrm{H}, \mathrm{H}^{\mathrm{A} 5}\right.$ and $\left.\mathrm{H}^{\mathrm{E} 5}\right)$ and 7.25 $\left(\mathrm{t}, 4 \mathrm{H}, \mathrm{H}^{\mathrm{F} 3}\right.$ and $\mathrm{H}^{\mathrm{G} 3}$ ). Mass spectrum (FAB): $m / z 1087$ (2) and $1008\left(2-\right.$ py). IR $\left(\tilde{v}_{\mathrm{CO}} / \mathrm{cm}^{-1}\right.$, Nujol mull): 1917 and 2029.

$\left[\operatorname{Re}^{\mathrm{III}}(\mathbf{q p y}) \mathrm{Cl}_{2}\right]\left[\mathrm{ClO}_{4}\right]$ 3. A suspension of $\left[\mathrm{ReOCl}_{3}\left(\mathrm{PPh}_{3}\right)_{2}\right]$ $(100 \mathrm{mg}, 0.12 \mathrm{mmol})$ and qpy $(46 \mathrm{mg}, 0.12 \mathrm{mmol})$ in degassed ethanol $\left(30 \mathrm{~cm}^{3}\right)$ was heated to reflux for $24 \mathrm{~h}$. The resulting deep blue solution was filtered and the filtrate treated with a saturated methanolic solution of $\mathrm{LiClO}_{4}$. Deep blue microcrystals precipitated upon cooling and were filtered off and recrystallized by diffusion of diethyl ether into an acetonitrile solution. Crystals suitable for X-ray analysis were obtained by slow evaporation of an acetonitrile solution of the [Re ${ }^{\text {III }}$ (qpy)$\left.\mathrm{Cl}_{2}\right]\left[\mathrm{ClO}_{4}\right]$ complex (Found for $\mathrm{MeCN}$ solvate: $\mathrm{C}, 41.55 ; \mathrm{H}$, $2.50 ; \mathrm{N}, 10.70$. Calc. for $\mathrm{C}_{27} \mathrm{H}_{20} \mathrm{Cl}_{3} \mathrm{~N}_{6} \mathrm{O}_{4} \mathrm{Re}: \mathrm{C}, 41.35 ; \mathrm{H}, 2.55$; $\mathrm{N}, 10.70 \%),{ }^{1} \mathrm{H}$ NMR $\left[270 \mathrm{MHz},\left(\mathrm{CD}_{3}\right)_{2} \mathrm{SO}\right.$, numbering scheme as in Scheme 2]: $\delta 8.99\left(\mathrm{~d}, 2 \mathrm{H}, \mathrm{H}^{\mathrm{A} 3}\right.$ and $\left.\mathrm{H}^{\mathrm{E} 3}\right), 8.89(\mathrm{~d}, 2$ $\mathrm{H}, \mathrm{H}^{\mathrm{B} 3 / \mathrm{B} 5}$ and $\left.\mathrm{H}^{\mathrm{D} 3 / \mathrm{D} 5}\right), 8.75\left(\mathrm{~d}, 2 \mathrm{H}, \mathrm{H}^{\mathrm{B} 3 / \mathrm{B} 5}\right.$ and $\left.\mathrm{H}^{\mathrm{D} 3 / \mathrm{D} 5}\right), 8.63$ $\left(\mathrm{d}, 2 \mathrm{H}, \mathrm{H}^{\mathrm{C} 3}\right.$ and $\left.\mathrm{H}^{\mathrm{C} 5}\right), 8.18\left(\mathrm{t}, 2 \mathrm{H}, \mathrm{H}^{\mathrm{A} 4}\right.$ and $\left.\mathrm{H}^{\mathrm{E} 4}\right), 7.83(\mathrm{t}, 2 \mathrm{H}$, $\mathrm{H}^{\mathrm{B} 4}$ and $\left.\mathrm{H}^{\mathrm{D} 4}\right), 7.51\left(\mathrm{t}, 2 \mathrm{H}, \mathrm{H}^{\mathrm{A} 5}\right.$ and $\left.\mathrm{H}^{\mathrm{E} 5}\right), 7.44\left(\mathrm{~d}, 2 \mathrm{H}, \mathrm{H}^{\mathrm{A} 6}\right.$ and $\mathrm{H}^{\mathrm{E} 6}$ ) and $7.41\left(\mathrm{t}, 1 \mathrm{H}, \mathrm{H}^{\mathrm{C} 4}\right)$. Mass spectrum (FAB): $m / z 644$ (3) and $609(3-\mathrm{Cl})$.

\section{Crystal structure determinations}

Complex 2. Crystal data. $\mathrm{C}_{41} \mathrm{H}_{27} \mathrm{Cl}_{2} \mathrm{~N}_{7} \mathrm{O}_{14} \mathrm{Re}_{2}, \quad M_{\mathrm{r}}=$ 1285.02, triclinic, space group $P \overline{\mathrm{I}}$ (no. 2), $a=8.739(2), b=$ 14.414(2), $c=18.717(3) \AA, \alpha=68.92(2), \beta=79.64(2), \gamma=$ $83.77(1)^{\circ}, U=2161.4(8) \AA^{3}, Z=2, D_{\mathrm{c}}=1.974 \mathrm{~g} \mathrm{~cm}^{-3}, \mu(\mathrm{Mo}-$ $\mathrm{K} \alpha)=57.98 \mathrm{~cm}^{-1}, F(000)=1236, T=298 \mathrm{~K}$.

A yellow, long thin needle crystal of dimensions $0.08 \times$ $0.05 \times 0.45 \mathrm{~mm}$ was used for data collection at $25^{\circ} \mathrm{C}$ on an Enraf-Nonius CAD4 diffractometer at The University of Hong Kong with graphite-monochromatized Mo-K $\alpha$ radiation $(\lambda=0.71073 \AA)$ using $\omega-2 \theta$ scans with $\omega$-scan angle $(0.75+$ $0.35 \tan \theta)^{\circ}$ at a scan speed of $1.73-5.49^{\circ} \mathrm{min}^{-1}$. Intensity data $\left(2 \theta_{\max }=42^{\circ} ; h 0-8, k-14\right.$ to $14, l-18$ to 18 ; three standard reflections measured every $2 \mathrm{~h}$ showed no decay) were corrected for Lorentz and polarization effects, and empirical absorption corrections were based on the $\psi$ scan of four strong reflections (minimum and maximum transmission factors 0.927 and 1.000). Upon averaging the 5035 reflections, 4638 of which were uniquely measured $\left(R_{\text {int }}=0.019\right), 3476$ with $I>3 \sigma(I)$ were observed and used in the structural analysis. The centric space group $P \overline{1}$ was confirmed in the successful refinement of the structure which was solved by heavy-atom Patterson methods and expanded using Fourier techniques and refined by fullmatrix least squares using the $\operatorname{TEXSAN~}^{9 a}$ package on a Silicon Graphics Indy computer. All non-H atoms were refined anisotropically. Hydrogen atoms were placed at calculated positions with thermal parameters equal to 1.3 times that of the attached atoms but not refined. Convergence for 595 variable parameters by least-squares refinement of $F$ with $w=4 F_{\mathrm{o}}{ }^{2} / \sigma^{2}\left(F_{\mathrm{o}}{ }^{2}\right)$, where $\sigma^{2}\left(F_{\mathrm{o}}{ }^{2}\right)=\left[\sigma^{2}(I)+(0.001\right.$ $\left.\left.F_{\mathrm{o}}{ }^{2}\right)^{2}\right]$ for 3476 reflections with $I>3 \sigma(I)$, was reached at $R=0.028$ and $R^{\prime}=0.026$ with a goodness of fit of 1.67 ; $(\Delta / \sigma)_{\max }=0.01$. The final Fourier-difference map was featureless, with maximum positive and negative peaks of 0.83 and 0.61 e $\AA^{-3}$ respectively.
Complex 3.MeCN. Crystal data. $\mathrm{C}_{27} \mathrm{H}_{20} \mathrm{Cl}_{3} \mathrm{~N}_{6} \mathrm{O}_{4} \mathrm{Re}, M_{\mathrm{r}}=$ 785.05, triclinic, space group $P \overline{1}, a=9.023(12), b=12.220(6)$, $c=13.729(6) \AA, \alpha=69.19(3), \beta=78.02(7), \gamma=83.69(8)^{\circ}$, $U=1383(2) \AA^{3}, Z=2, D_{\mathrm{c}}=1.885 \mathrm{~g} \mathrm{~cm}^{-3}, \mu($ Mo-K $\alpha)=$ $47.83 \mathrm{~cm}^{1}$, crystal dimensions $0.20 \times 0.20 \times 0.20 \mathrm{~mm}$, $F(000)=764$

Intensity data were collected as for complex 2, at National Taiwan University, using the $\omega-2 \theta$ scan mode with $2 \theta_{\max }=$ $45.0^{\circ}$. The crystal quality was not good. The peak width for the $\theta-2 \theta$ scan was $1.1^{\circ}$ in $\theta$ and $2.2^{\circ}$ in $2 \theta$. An empirical $\psi$-scan absorption correction was applied. Three sets of reflections with $\chi$ values close to $90^{\circ}$ and $10^{\circ}$ intervals in $\psi$ were collected. A total of 111 reflections were collected and the absorption curve as a function of $\psi$ was obtained and applied for absorption correction. ${ }^{10}$ All data reduction and structure refinement were performed using the NRCC-SDP-VAX package. ${ }^{9 b}$ The structure was solved by the Patterson method and refined by least squares. The weighting scheme was $w^{-1}=\sigma^{2}(F)$. The last least-squares cycle was calculated with 61 atoms, 371 parameters and 3022 reflections $\left(\left|I_{\mathrm{o}}\right|>2.0 \sigma\left|I_{\mathrm{o}}\right|\right)$ of 3606 unique reflections, giving $R=0.058, R^{\prime}=0.057$, goodness of fit $=$ 3.82. The final Fourier-difference map showed residual extrema in the range of -2.850 to 2.370 e $\AA^{-3}$. The atomic coordinates of the complexes are listed in Table 2 and selected bond distances and angles in Table 1 .

Complete atomic coordinates, thermal parameters and bond lengths and angles have been deposited at the Cambridge Crystallographic Data Centre. See Instructions for Authors, J. Chem. Soc., Dalton Trans., 1996, Issue 1.

\section{Results and Discussion}

The synthesis of $2,2^{\prime}: 6^{\prime}, 2^{\prime \prime}: 6^{\prime \prime}, 2^{\prime \prime \prime}: 6^{\prime \prime \prime}, 2^{\prime \prime \prime \prime}$-quinquepyridine by the Kröhnke method resulted in a high yield. The co-ordination versatility of qpy and related compounds has been demonstrated by the formation of many mono- and bi-metallic, single- and double-helical transition-metal complexes. Examples include $\left[\mathrm{Fe}_{2} \text { (bmsqpy) }{ }_{2}\left(\mathrm{O}_{2} \mathrm{CMe}\right)\right]^{3+11}\left[\right.$ bmsqpy $=4^{\prime}, 4^{\prime \prime \prime}$-bis(methylsulfanyl)-2,2': $6^{\prime}, 2^{\prime \prime}: 6^{\prime \prime}, 2^{\prime \prime \prime}: 6^{\prime \prime \prime}, 2^{\prime \prime \prime \prime}$-quinquepyridine $], \quad\left[\mathrm{Co}_{2}(\mathrm{qpy})_{2}-\right.$ $\left.\left(\mathrm{O}_{2} \mathrm{CMe}\right)\right]^{3+},{ }^{5 e} \quad\left[\mathrm{Co}_{2}(\mathrm{qpy})_{2}\right]^{4+},{ }^{5 e} \quad\left[\mathrm{Co}(\mathrm{bcpqpy})\left(\mathrm{H}_{2} \mathrm{O}\right)-\right.$ $(\mathrm{MeOH})]^{2+5 f, g} \quad\left[\right.$ bcpqpy $=4^{\prime}, 4^{\prime \prime \prime}-$-bis $\left(p\right.$-chlorophenyl)-2,2' $2^{\prime} 6^{\prime}$ $2^{\prime \prime}: 6^{\prime \prime}, 2^{\prime \prime \prime}: 6^{\prime \prime \prime}, 2^{\prime \prime \prime \prime}$-quinquepyridine $), \quad\left[\mathrm{Ni}_{2}(\mathrm{qpy})_{2}\left(\mathrm{O}_{2} \mathrm{CMe}\right)\right]^{3+},{ }^{3 d}$ $\left[\mathrm{Cu}_{2}(\mathrm{qpy})_{2}\left(\mathrm{O}_{2} \mathrm{CMe}\right)\right]^{3+},{ }_{a, c} \quad\left[\mathrm{Zn}_{2}(\text { bmsqpy })_{2}\left(\mathrm{O}_{2} \mathrm{CMe}\right)\right]^{3+, 11}$ $\left[\mathrm{Pd}_{2}(\mathrm{qpy})_{2}\right]^{4+5 h}$ and $[\mathrm{Ag}(\mathrm{qpy})]^{+} .5 b$ Scheme 1 illustrates the three possible bonding modes of qpy. It usually functions as two discrete units (mode 1) but there are some cases where it acts as a pentadentate unit (mode 2 ) in which all the five pyridyl donors co-ordinate to one metal centre. In addition, there is a special bonding mode, in $\left[\mathrm{Pd}_{2}(\mathrm{qpy})_{2}\right]^{4+},{ }^{5 h}$ in which each
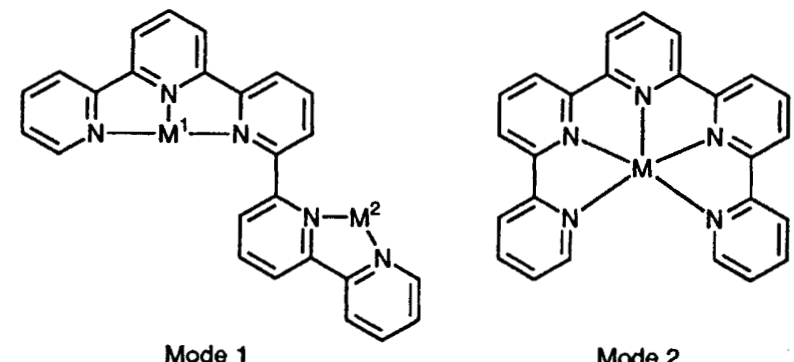

Mode 2

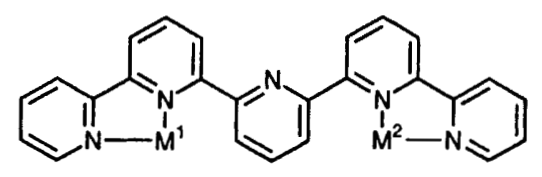

Mode 3

Scheme 1 The three possible co-ordination modes of qpy with transition-metal cations 


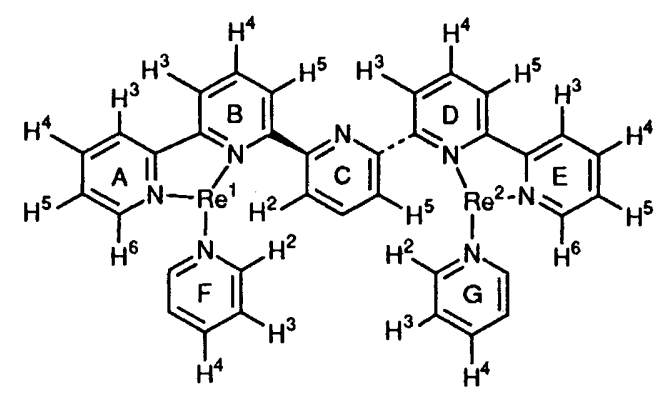

$\left[(p y)(O C)_{3} \operatorname{Re}^{\mathrm{l}}(\mathrm{qpy}) \operatorname{Re}^{\mathrm{I}}(\mathrm{CO})_{3}(\mathrm{py})\right]^{2+} 2$

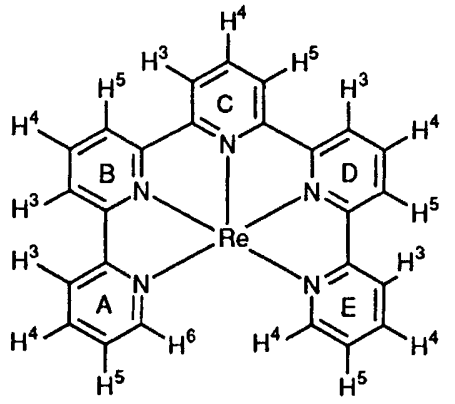

$\left[\mathrm{Re}^{\mathrm{III}}(\mathrm{qpy}) \mathrm{Cl}_{2}\right]^{+} 3$

Scheme 2 Numbering scheme of hydrogens and pyridyl rings of qpy rhenium complexes for assignment of ${ }^{1} \mathrm{H}$ NMR spectra; for simplicity, bonded carbonyls of $\mathbf{2}$ and chlorides of $\mathbf{3}$ are omitted

palladium is in an irregular five-co-ordinate environment with four short contacts $(1.941-2.085 \AA)$ to a terpyridyl fragment of one ligand and a terminal pyridine from the other. The coordination sphere is completed by a long contact $(\approx 2.6 \AA)$ to the remaining pyridine of the second ligand.

Scheme 2 shows the numbering scheme of the hydrogen atoms and pyridyl rings of qpy in complexes 2 and 3 . In complexes 1 and 2 the bonding of the qpy ligand could be in the fashion bipy-py-bipy (mode 3 , bipy = bipyridine fragment and py = pyridine spacer). This co-ordination mode could be rationalized by the fact that the $\operatorname{Re}^{\mathrm{I}}(\mathrm{CO})_{3}$ unit usually possesses a fac geometry. ${ }^{1,2}$ Furthermore, owing to the higher steric hindrance encountered in forming the py-(Re-bipy)-(bipy-Re) bonding mode, the (Re-bipy)-py-(bipy-Re) mode is preferred. The solubility of complex 1 is very poor, but $\mathbf{2}$ has much higher solubility in $\mathrm{MeCN}$ and $\mathrm{MeOH}$. The synthesis of $\left[\mathrm{Re}^{\mathrm{III}}(\mathrm{qpy}) \mathrm{Cl}_{2}\right]^{+} \mathbf{3}$ is suggested to proceed through in situ reduction of $\left[\mathrm{Re}^{\mathrm{v}} \mathrm{OCl}_{3}(\mathrm{PPh})_{2}\right]$ in ethanol. Rhenium(III) complexes containing pyridine-type ligands are not extensive. Some examples include $\left[\mathrm{ReCl}_{3}(\right.$ bipy $\left.)\left(\mathrm{PPh}_{3}\right)\right]$ (bipy $=2,2^{\prime}$-bipyridine $)^{12}\left[\mathrm{ReCl}(2 \mathrm{Me} \text {-py)(en })_{2}\right]^{2+13}(2 \mathrm{Me}$-py $=2$-methylpyridine, en $=1,2$-diaminoethane $),\left[\mathrm{ReO}(\text { terpy })\left(\mathrm{SC}_{6} \mathrm{H}_{4} \mathrm{Me}-p\right)_{2}\right]^{+14}$ and very recently $\left[\mathrm{Re}(\text { terpy })_{2} \mathrm{Cl}\right]^{2+15}$ (terpy $=2,2^{\prime}: 6^{\prime}, 2^{\prime \prime}$-terpyridine). None of them was prepared from $\left[\mathrm{ReOCl}_{3}\left(\mathrm{PPh}_{3}\right)_{2}\right]$ despite the fact that it is a useful starting material for the rhenium(III) complexes of phosphines and alkyl isocyanides. ${ }^{16}$ It is interesting that the reaction between $\left[\mathrm{ReOCl}_{3}\left(\mathrm{PPh}_{3}\right)_{2}\right]$ and $2,2^{\prime}: 6^{\prime}, 2^{\prime \prime}: 6^{\prime \prime}, 2^{\prime \prime \prime}$-quaterpyridine (qtpy) under similar reaction conditions as in the preparation of $\mathbf{3}$ gives $\left[\mathrm{Re}^{\mathrm{v}} \text { (qtpy)O(OMe) }\right]_{2}^{+}{ }^{+4}$

The crystal structures of complexes 2 and 3. MeCN have been determined. Figs. 1 and 2 show perspective views of the cations $\left[(\text { py })(\mathrm{OC})_{3} \operatorname{Re}(q p y) \operatorname{Re}(\mathrm{CO})_{3}(\text { py })\right]^{2+}$ and $\left[\operatorname{Re}(\text { qpy }) \mathrm{Cl}_{2}\right]^{+}$respectively. The structures feature the first examples of rheniumqpy complexes. Although two kinds of crystal were found for $\mathbf{2}$, only the structure of the needle-shaped crystal was determined. As shown in Fig. 1, the complex adopts a bimetallic monohelical structure with each rhenium atom in a distortedoctahedral geometry and the three carbonyls in a fac

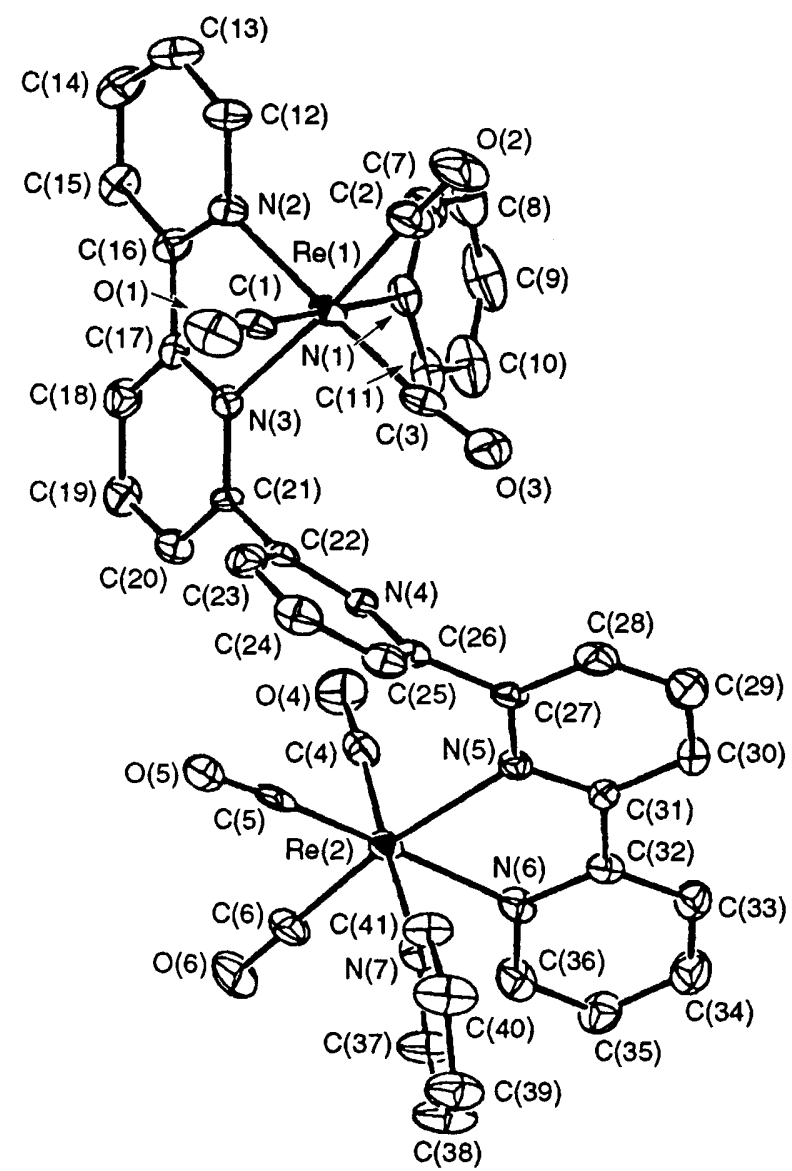

Fig. 1 Perspective view of complex 2

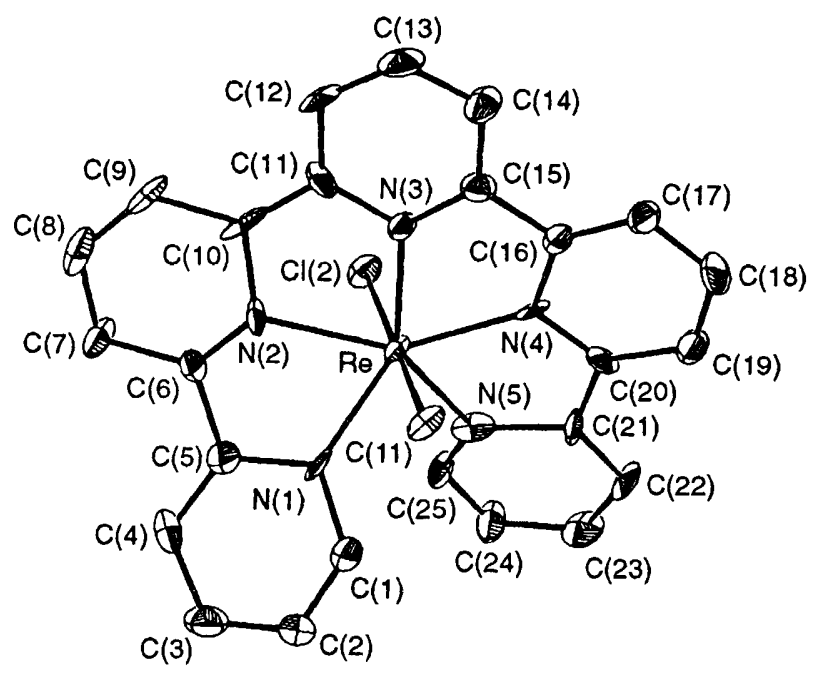

Fig. 2 Perspective view of complex 3

arrangement. The measured $\mathrm{Re}-\mathrm{N}$ distances range from $2.154(8)$ to $2.225(8) \AA$, which are comparable to the related values in $\left[\operatorname{Re}^{\mathrm{I}}(\text { diimine })(\mathrm{CO})_{3}(\mathrm{py})\right]^{+}$complexes such as $\left[\operatorname{Re}(\mathrm{dmphen})(\mathrm{CO})_{3}(\mathrm{py})\right]^{+}(\mathrm{dmphen}=4,7-$ dimethyl-1,10-phenanthroline. ${ }^{17}$ There is no $\pi-\pi$ interaction within the monohelical bimetallic complex. The two pyridines, the two bipyridine units and the central 1,3-pyridyl spacer are essentially planar. With reference to the numbering scheme given in Scheme 2 , the dihedral angle between planes 1 (ring F) and 2 (A and B) is $120.50^{\circ}$, that between $3(\mathrm{G})$ and $4(\mathrm{D}$ and $\mathrm{E})$ is $96.63^{\circ}$. The dihedral angles between the pyridyl spacer plane 5 (ring $\mathrm{C}$ ) and planes $1,2,3$ and 4 are $55.00,110.39,53.53$ and $112.01^{\circ}$ respectively. The principal twists of the interpyridyl bonds of the qpy ligand in $\mathbf{2}$ occur at $\mathrm{C}(21)-\mathrm{C}(22)$ (between planes 2 and 5 ) and $\mathrm{C}(26)-\mathrm{C}(27)$ (between 5 and 4 ) with dihedral angles 
Table 1 Selected bond distances $(\AA)$ and angles $\left(^{\circ}\right)$ of $\left[(\mathrm{py})(\mathrm{OC})_{3} \mathrm{Re}^{\mathrm{l}-}\right.$ (qpy) $\left.\operatorname{Re}^{\mathrm{I}}(\mathrm{CO})_{3}(\mathrm{py})\right]\left[\mathrm{ClO}_{4}\right]_{2} 2$ and $\left[\mathrm{Re}^{\mathrm{III}}(\mathrm{qpy}) \mathrm{Cl}_{2}\right]\left[\mathrm{ClO}_{4}\right] \cdot \mathrm{MeCN}^{3}$

Complex 2

$\operatorname{Re}(1)-\mathrm{N}(1)$

$\operatorname{Re}(1)-\mathrm{N}(2)$

$\operatorname{Re}(1)-\mathrm{N}(3)$

$\operatorname{Re}(2)-\mathrm{N}(5)$

$2.225(8)$

$2.154(8)$

$2.216(7)$

$2.223(7)$

$\operatorname{Re}(2)-\mathrm{N}(6) \quad 2.161(8)$

$\operatorname{Re}(2)-\mathrm{N}(7) \quad 2.169(8)$

$\mathrm{N}(1)-\operatorname{Re}(1)-\mathrm{C}(1)$

$\mathrm{N}(2)-\operatorname{Re}(1)-\mathrm{C}(3)$

$\mathrm{N}(3)-\operatorname{Re}(1)-\mathrm{C}(2)$

$\mathrm{N}(5)-\operatorname{Re}(2)-\mathrm{C}(6)$

$\mathrm{N}(6)-\operatorname{Re}(2)-\mathrm{C}(5)$

$\mathrm{N}(7)-\operatorname{Re}(2)-\mathrm{C}(4)$

$176.1(4)$

$172.8(4)$

$173.5(4)$

$171.0(4)$

$174.9(4)$

177.1(4)

Complex 3

$\mathrm{Re}-\mathrm{Cl}$

$2.430(5)$

$\mathrm{Re}-\mathrm{N}(1) \quad 2.073(14)$

Re-N(2) 2.104(13)

$\operatorname{Re}-\mathrm{N}(3) \quad 2.071(13)$

$\mathrm{Re}-\mathrm{N}(4) \quad 2.050(14)$

$\mathrm{Re}-\mathrm{N}(5) \quad 2.164(13)$

$\mathrm{Cl}-\mathrm{Re}-\mathrm{Cl}$

$\mathrm{N}(1)-\mathrm{Re}-\mathrm{N}(2)$

$\mathrm{N}(2)-\operatorname{Re}-\mathrm{N}(3)$

$\mathrm{N}(3)-\operatorname{Re}-\mathrm{N}(4)$

$\mathrm{N}(4)-\mathrm{Re}-\mathrm{N}(5)$

$\mathrm{N}(5)-\operatorname{Re}-\mathrm{N}(1)$

$178.5(2)$

$70.8(5)$

$77.3(5)$

$70.7(5)$

$75.1(5)$

$75.3(5)$

being 110.39 and $112.01^{\circ}$ respectively. There are minor twists at the interpyridyl bonds of the two bipyridine units (3.98 and $7.55^{\circ}$ respectively). The $\operatorname{Re} \cdots \operatorname{Re}$ separation is $7.723 \AA$, which precludes any direct interaction.

Seven-co-ordinated rhenium(III) complexes have been reported ${ }^{15,18}$ and the ones containing pyridine-type ligands are $\left[\mathrm{Re}(\text { terpy })_{2} \mathrm{X}\right]^{2+}\left(\mathrm{X}=\mathrm{Cl}^{-}, \mathrm{OH}^{-}\right.$or $\left.\mathrm{NCS}^{-}\right) .{ }^{15}$ The rhenium atom in the monohelical $\left[\mathrm{Re}(q p y) \mathrm{Cl}_{2}\right]^{+}$complex 3 is in a distorted pentagonal-bipyramid geometry with the two $\mathrm{Cl}$ atoms trans to each other $\left[\mathrm{Cl}(1)-\mathrm{Re}-\mathrm{Cl}(2) 178.53^{\circ}\right]$. The two measured $\mathrm{Re}-\mathrm{Cl}$ distances $[2.430(5) \AA]$ are much longer than that of the other related trans-dichlororhenium(III) complexes such as $2.337(1) \AA$ in $\left[\operatorname{Re}(d m p e){ }_{2} \mathrm{Cl}_{2}\right]^{+},{ }^{19} 2.322(3)$ and $2.331(3)$ $\AA$ in $\left[\mathrm{ReCl}_{2}\left(\mathrm{CNPr}^{\mathrm{i}}\right)_{2}\left(\mathrm{PMePh}_{2}\right)_{2}\right]^{+18 a}$ and $2.349(1) \AA$ in $\left[\operatorname{ReCl}_{2}(\text { ampy })_{2}\right]^{+13}$ where ampy $=2$-(aminomethyl)pyridine and dmpe $=1,2$-bis(dimethylphosphino)ethane. This could be rationalized by the rhenium atom in the seven-co-ordinated complex 3 being more electron rich than that in six-coordinated complexes.

The ${ }^{1} \mathrm{H}$ NMR spectra of the two forms of complex 2 in $\mathrm{CD}_{3} \mathrm{CN}$ at $-35^{\circ} \mathrm{C}$ are shown in Fig. 3. Owing to the restriction imposed by the facial geometry of the two tricarbonylrhenium(I) units, only three stereoisomers (each has its enantiomer) are feasible, the structures of which are illustrated in Scheme 3. As described in the Experimental section, only two kinds of crystals of 2 , the yellow needles and prisms, have been obtained. From the X-ray analysis the needle crystal corresponds to isomer 2a. As there exists no mirror plane nor rotational symmetry in $2 \mathrm{a}$, its ${ }^{1} \mathrm{H}$ NMR spectrum is more complex than that of $\mathbf{2 b}$ and $\mathbf{2 c}$. The spectrum of the yellow prism crystals reveals a centre of symmetry in the molecule. As a result, it could be isomer $\mathbf{2 b}$ or 2c, both of which have a two-fold rotational axis. These two isomers could interconvert through rotation of the interannular bonds between rings $\mathrm{C}$ and $\mathrm{D}$ and $\mathrm{D}$ and $\mathrm{E}$ (Scheme 3). The infrared spectra for 1 and 2 display two carbonylstretching bands, consistent with a facial tricarbonyl structure. ${ }^{1}$ The absorption, emission and photophysical data of 1 and 2 are listed in Table 3. The absorption spectra show broad and structureless lowest-energy absorptions at 350-385 $\mathrm{nm}$, which are very similar to the metal-to-ligand chargetransfer (m.l.c.t.) transitions of fac- $\left[\operatorname{Re}(\text { bipy })(\mathrm{CO})_{3} \mathrm{Y}\right]^{n+}(\mathrm{Y}=$ $\mathrm{Cl}$ or py), ${ }^{1,2}$ and hence they are tentatively assigned as $\pi^{*}$ (qpy) $\longleftarrow d_{\pi}\left(\operatorname{Re}^{\mathrm{I}}\right)$ charge transfer in nature. Complexes 1 and 2 show photoluminescence in the spectral range $560-600 \mathrm{~nm}$. The emission spectra of 2 measured in $\mathrm{MeOH}$ at room temperature and at $77 \mathrm{~K}$ are shown in Fig. 4. The excitation spectra closely match the corresponding absorption spectra. In both cases the emission bands are broad and featureless. For 2 the emission maximum measured in methanol glass at $77 \mathrm{~K}$ shows a substantial blue shift of $1320 \mathrm{~cm}^{-1}$ when compared (a)

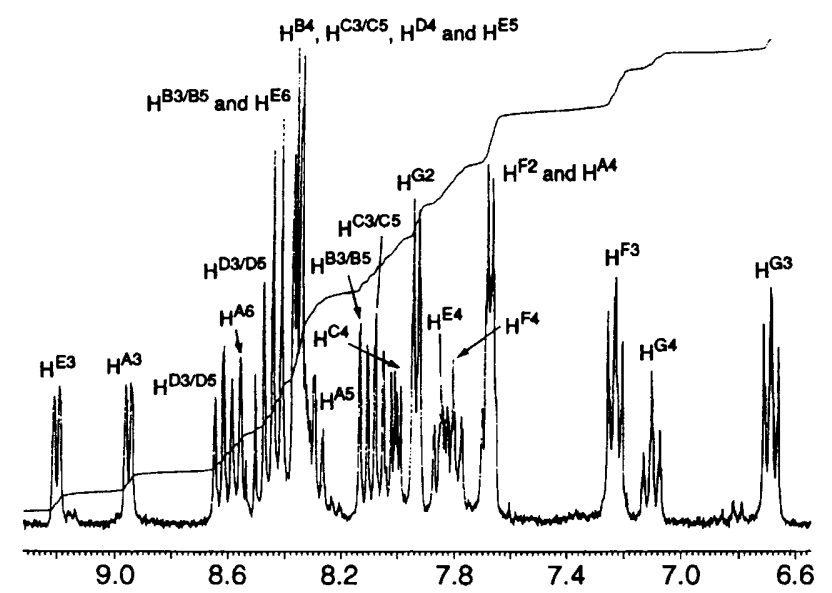

(b)

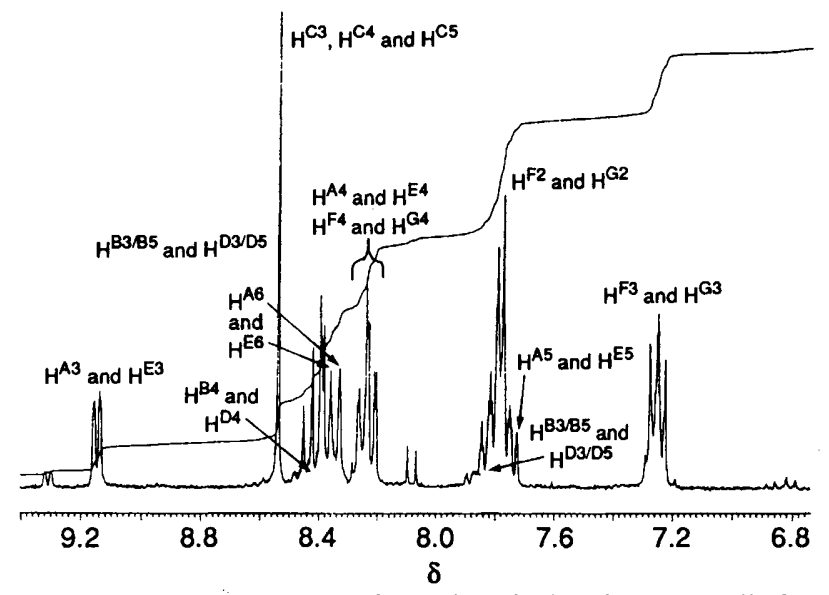

Fig. 3 Proton NMR spectra of complex 2 in $\mathrm{CD}_{3} \mathrm{CN}$ : $(a)$ needle-form crystal, (b) prism-form crystal

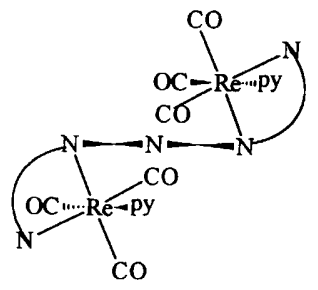

2a

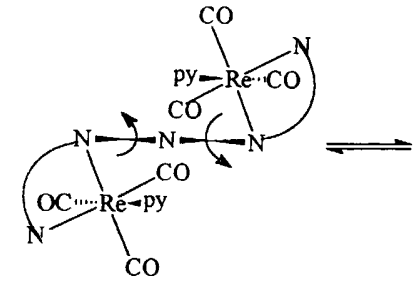

2b

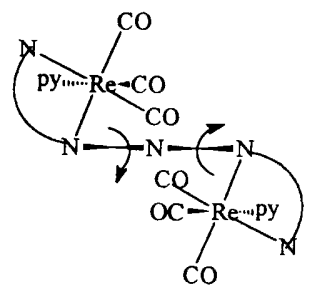

$2 c$
Scheme 3 The three stereoisomers of complex 2

with that recorded in the same solvent at room temperature. Changing the solvent from $\mathrm{CH}_{2} \mathrm{Cl}_{2}$ to $\mathrm{MeCN}$ also causes a blue shift of the emission maximum and shortening of the luminescence lifetime. These observations are reminiscent of the m.l.c.t. excited state of rhenium(I)- $\alpha, \alpha^{\prime}$-diimine complexes. $^{1,2}$

The ${ }^{1} \mathrm{H}$ NMR spectrum of complex 3 in $\left(\mathrm{CD}_{3}\right)_{2} \mathrm{SO}$ with assignments is given in Fig. 5. It can be rationalized on the basis 
Table 2 Atomic coordinates of non-hydrogen atoms for complexes 2 and 3

\begin{tabular}{|c|c|c|c|c|c|c|c|}
\hline \multirow{2}{*}{\multicolumn{8}{|c|}{ Atom }} \\
\hline & & & & & & & \\
\hline $\operatorname{Re}(1)$ & $0.25596(5)$ & $0.24692(3)$ & $0.03261(2)$ & $C(9)$ & $0.724(2)$ & $0.424(1)$ & $0.018(1)$ \\
\hline $\operatorname{Re}(2)$ & $0.18870(5)$ & $0.20616(3)$ & $0.45985(2)$ & $C(10)$ & $0.628(2)$ & $0.3882(10)$ & $0.0876(10)$ \\
\hline$C(1)$ & $0.1173(4)$ & $0.1727(2)$ & $0.7856(2)$ & C(11) & $0.495(1)$ & $0.3427(8)$ & $0.088 \mathrm{l}(7)$ \\
\hline$C(2)$ & $0.5058(5)$ & $0.5020(4)$ & $0.2747(2)$ & $C(12)$ & $0.460(1)$ & $0.1888(8)$ & $-0.1022(6)$ \\
\hline$O(1)$ & $-0.012(1)$ & $0.1185(7)$ & $0.0466(5)$ & $C(13)$ & $0.592(2)$ & $0.153(1)$ & $-0.1375(6)$ \\
\hline$O(2)$ & $0.121(1)$ & $0.3952(7)$ & $-0.1072(5)$ & $C(14)$ & $0.704(1)$ & $0.0977(9)$ & $-0.0954(8)$ \\
\hline$O(3)$ & $0.0347(9)$ & $0.3702(6)$ & $0.1128(4)$ & $C(15)$ & $0.678(1)$ & $0.0782(8)$ & $0.0170(7)$ \\
\hline$O(4)$ & $0.5084(10)$ & $0.2022(6)$ & $0.3601(5)$ & $C(16)$ & $0.544(1)$ & $0.1144(7)$ & $0.0176(6)$ \\
\hline $\mathrm{O}(5)$ & $0.102(1)$ & $0.0354(6)$ & $0.4160(4)$ & $C(17)$ & $0.507(1)$ & $0.0958(7)$ & $0.1015(6)$ \\
\hline$O(6)$ & $0.320(1)$ & $0.0394(6)$ & $0.5912(5)$ & $C(18)$ & $0.605(1)$ & $0.0410(8)$ & $0.1531(7)$ \\
\hline$O(7)$ & $0.394(1)$ & $0.464(1)$ & $0.2492(8)$ & $\mathrm{C}(19)$ & $0.564(1)$ & $0.0215(8)$ & $0.2308(7)$ \\
\hline $\mathrm{O}(8)$ & $0.624(1)$ & $0.528(2)$ & $0.2204(8)$ & $C(20)$ & $0.421(1)$ & $0.0580(8)$ & $0.2567(6)$ \\
\hline$O(9)$ & $0.438(2)$ & $0.593(1)$ & $0.290(1)$ & $\mathrm{C}(21)$ & $0.321(1)$ & $0.1152(7)$ & $0.2046(5)$ \\
\hline$O(10)$ & $0.537(2)$ & $0.4367(9)$ & $0.3449(7)$ & $\mathrm{C}(22)$ & $0.168(1)$ & $0.1541(7)$ & $0.2329(5)$ \\
\hline$O(11)$ & $0.265(1)$ & $0.2047(7)$ & $0.7499(6)$ & $C(23)$ & $0.032(1)$ & $0.1129(8)$ & $0.2328(6)$ \\
\hline$O(12)$ & $0.113(1)$ & $0.1442(9)$ & $0.8647(6)$ & $C(24)$ & $-0.107(1)$ & $0.1503(9)$ & $0.2606(6)$ \\
\hline$O(13)$ & $0.001(1)$ & $0.2457(7)$ & $0.7596(7)$ & $C(25)$ & $-0.107(1)$ & $0.2269(8)$ & $0.2875(6)$ \\
\hline$O(14)$ & $0.086(1)$ & $0.0900(6)$ & $0.7714(7)$ & $C(26)$ & $0.033(1)$ & $0.2605(7)$ & $0.2876(5)$ \\
\hline$N(1)$ & $0.4589(10)$ & $0.3327(6)$ & $0.0249(5)$ & $C(27)$ & $0.039(1)$ & $0.3484(7)$ & $0.3113(5)$ \\
\hline $\mathrm{N}(2)$ & $0.4346(9)$ & $0.1722(6)$ & $-0.0254(4)$ & $\mathrm{C}(28)$ & $-0.028(1)$ & $0.4389(9)$ & $0.2665(6)$ \\
\hline$N(3)$ & $0.3664(9)$ & $0.1347(5)$ & $0.1274(4)$ & $C(29)$ & $-0.020(1)$ & $0.5237(9)$ & $0.2812(7)$ \\
\hline$N(4)$ & $0.1714(9)$ & $0.2252(6)$ & $0.2618(4)$ & $C(30)$ & $0.054(1)$ & $0.5203(7)$ & $0.3411(6)$ \\
\hline N(5) & $0.1048(9)$ & $0.3442(6)$ & $0.3726(4)$ & C(31) & $0.115(1)$ & $0.4280(7)$ & $0.3872(5)$ \\
\hline$N(6)$ & $0.2304(9)$ & $0.3263(6)$ & $0.4961(5)$ & $C(32)$ & $0.191(1)$ & $0.4192(8)$ & $0.4533(5)$ \\
\hline$N(7)$ & $-0.0405(9)$ & $0.2114(6)$ & $0.5263(5)$ & $C(33)$ & $0.222(1)$ & $0.5008(8)$ & $0.4712(6)$ \\
\hline$C(1)$ & $0.093(1)$ & $0.1665(8)$ & $0.0412(6)$ & C(34) & $0.288(1)$ & $0.4883(9)$ & $0.5340(7)$ \\
\hline$C(2)$ & $0.180(1)$ & $0.3407(9)$ & $-0.0573(7)$ & $C(35)$ & $0.324(1)$ & $0.3935(10)$ & $0.5796(7)$ \\
\hline$C(3)$ & $0.121(1)$ & $0.3185(9)$ & $0.0862(6)$ & $C(36)$ & $0.295(1)$ & $0.3145(8)$ & $0.5605(7)$ \\
\hline$C(4)$ & $0.388(1)$ & $0.2070(7)$ & $0.3969(6)$ & $C(37)$ & $-0.061(1)$ & $0.2009(9)$ & $0.6011(6)$ \\
\hline $\mathrm{C}(5)$ & $0.133(1)$ & $0.1036(8)$ & $0.4300(5)$ & $\mathrm{C}(38)$ & $-0.203(1)$ & $0.201(1)$ & $0.6469(6)$ \\
\hline$C(6)$ & $0.269(1)$ & $0.1005(8)$ & $0.5431(6)$ & $C(39)$ & $-0.337(1)$ & $0.210(1)$ & $0.6159(7)$ \\
\hline$C(7)$ & $0.555(1)$ & $0.3716(8)$ & $-0.0424(7)$ & $C(40)$ & $-0.318(1)$ & $0.220(1)$ & $0.5391(7)$ \\
\hline $\mathrm{C}(8)$ & $0.688(2)$ & $0.4178(9)$ & $-0.0478(10)$ & $C(41)$ & $-0.170(2)$ & $0.2193(9)$ & $0.4989(6)$ \\
\hline \multicolumn{8}{|c|}{ Complex 3} \\
\hline $\operatorname{Re}$ & $0.0119(1)$ & $0.20890(7)$ & $0.15066(6)$ & $C(13)$ & $-0.3706(24)$ & $-0.0124(18)$ & $0.1082(16)$ \\
\hline $\mathrm{Cl}(1)$ & $-0.1467(5)$ & $0.3820(4)$ & $0.0810(4)$ & $C(14)$ & $-0.2679(22)$ & $0.0475(18)$ & $0.0222(15)$ \\
\hline $\mathrm{Cl}(2)$ & $0.1647(5)$ & $0.0332(4)$ & $0.2233(4)$ & $C(15)$ & $-0.1603(21)$ & $0.1098(16)$ & $0.0379(14)$ \\
\hline $\mathrm{N}(1)$ & $0.0459(16)$ & $0.3055(12)$ & $0.2409(11)$ & $C(16)$ & $-0.0445(21)$ & $0.1757(15)$ & $-0.0448(13)$ \\
\hline $\mathrm{N}(2)$ & $-0.1144(18)$ & $0.1388(13)$ & $0.3046(10)$ & $C(17)$ & $-0.0360(22)$ & $0.1930(17)$ & $-0.1495(14)$ \\
\hline$N(3)$ & $-0.1466(17)$ & $0.1128(12)$ & $0.1297(10)$ & $C(18)$ & $0.086(3)$ & $0.2578(18)$ & $-0.2207(14)$ \\
\hline N(4) & $0.0514(16)$ & $0.2177(12)$ & $-0.0044(11)$ & $C(19)$ & $0.1840(21)$ & $0.3030(16)$ & $-0.1834(14)$ \\
\hline$N(5)$ & $0.2414(14)$ & $0.2674(12)$ & $0.0882(12)$ & $C(20)$ & $0.1657(21)$ & $0.2783(16)$ & $-0.0770(13)$ \\
\hline$C(1)$ & $0.0972(22)$ & $0.4145(16)$ & $0.2066(14)$ & $C(21)$ & $0.2785(22)$ & $0.3080(15)$ & $-0.0286(12)$ \\
\hline$C(2)$ & $0.1316(23)$ & $0.4720(17)$ & $0.2660(15)$ & $C(22)$ & $0.4233(21)$ & $0.3518(17)$ & $-0.0752(14)$ \\
\hline$C(3)$ & $0.1103(23)$ & $0.4192(18)$ & $0.3755(17)$ & $C(23)$ & $0.5206(21)$ & $0.3520(18)$ & $-0.0090(16)$ \\
\hline$C(4)$ & $0.0407(25)$ & $0.3101(19)$ & $0.4194(14)$ & $C(24)$ & $0.4854(22)$ & $0.3057(18)$ & $0.0987(14)$ \\
\hline$C(5)$ & $0.0118(22)$ & $0.2578(16)$ & $0.3525(15)$ & $C(25)$ & $0.3433(20)$ & $0.2664(16)$ & $0.1407(12)$ \\
\hline $\mathrm{C}(6)$ & $-0.0841(21)$ & $0.1566(16)$ & $0.3835(13)$ & $\mathrm{Cl}(3)$ & $0.3508(6)$ & $0.7108(5)$ & $0.3311(4)$ \\
\hline$C(7)$ & $-0.1469(21)$ & $0.0932(17)$ & $0.4907(14)$ & $O(I)$ & $0.1985(17)$ & $0.7064(15)$ & $0.3686(12)$ \\
\hline $\mathrm{C}(8)$ & $-0.2500(24)$ & $0.0086(18)$ & $0.5067(15)$ & $O(2)$ & $0.4116(22)$ & $0.7687(17)$ & $0.3819(12)$ \\
\hline $\mathrm{C}(9)$ & $-0.2894(22)$ & $-0.0119(16)$ & $0.4222(15)$ & $O(3)$ & $0.3683(19)$ & $0.7723(15)$ & $0.2166(12)$ \\
\hline$C(10)$ & $-0.2278(20)$ & $0.0542(15)$ & $0.3102(16)$ & $O(4)$ & $0.4229(23)$ & $0.6035(15)$ & $0.3445(15)$ \\
\hline$C(11)$ & $-0.2537(22)$ & $0.0502(17)$ & $0.2143(13)$ & $\mathrm{N}$ & $0.4618(24)$ & $0.2333(17)$ & $0.3636(14)$ \\
\hline \multirow[t]{2}{*}{$C(12)$} & $-0.3624(21)$ & $-0.0132(17)$ & $0.2051(15)$ & $C(26)$ & $0.537(3)$ & $0.3038(21)$ & $0.3642(17)$ \\
\hline & & & & $C(27)$ & $0.637(3)$ & $0.3874(20)$ & $0.3592(19)$ \\
\hline
\end{tabular}

Table 3 Absorption, emission and photophysical data for complexes 1 and 2

$\begin{array}{lllcl}\text { Complex } & \text { Absorption, }{ }^{a} \lambda / & & \\ \mathbf{1}^{c} & \mathrm{~nm}\left(\varepsilon / \mathrm{dm}^{3} \mathrm{~mol}^{-1} \mathrm{~cm}^{-1}\right) & \text { Emission, }{ }^{a} \lambda / \mathrm{nm} & \tau_{\mathbf{0}}{ }^{b} / \mathrm{ns} & \varphi_{\mathrm{r}}{ }^{b} \\ \mathbf{2}^{c} & 385(5670) & 605 & 50 & 8.5 \times 10^{-4} \\ \mathbf{2}^{d} & 360(12600) & 565^{c} & 400 & 0.038 \\ \mathbf{2}^{e} & 350(13600) & 570 & 250 & 0.017 \\ \mathbf{2}^{f} & 350(13000) & 570 & 240 & 0.017\end{array}$

\footnotetext{
${ }^{a}$ Absorptions and emissions of the lowest-energy maxima. ${ }^{b}$ Lifetimes and luminescence yields were obtained by monitoring the corresponding lowest-energy emission maxima at $298 \mathrm{~K}$ and the luminescence yield data are referenced to [ $\left.\mathrm{Ru}(\text { bipy })_{3}\right]^{2+}$ in degassed water. ${ }^{\mathrm{C}}$ In $\mathrm{CH}_{2} \mathrm{Cl}_{2}$ solution at $298 \mathrm{~K} .{ }^{d}$ In MeCN solution at $298 \mathrm{~K} .{ }^{e}$ In $\mathrm{MeOH}$ solution at $297 \mathrm{~K} .{ }^{f}$ In $\mathrm{MeOH}$ glass matrix at $77 \mathrm{~K}$.
}

of first-order coupling and shows five doublets and four triplets indicating a centre of symmetry on the qpy ligand. The protons are all displaced downfield compared with those in other double-helical transition-metal complexes of qpy. ${ }^{5,6}$ Presum- 


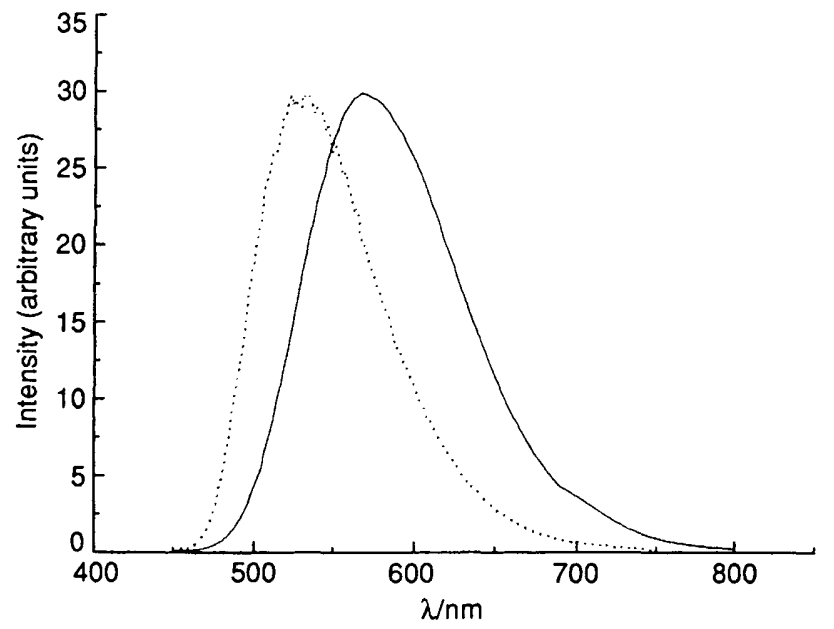

Fig. 4 Emission spectra of complex 2 measured in $\mathrm{MeOH}$ at 298 $(-)$ and $77 \mathrm{~K}(\cdots)$

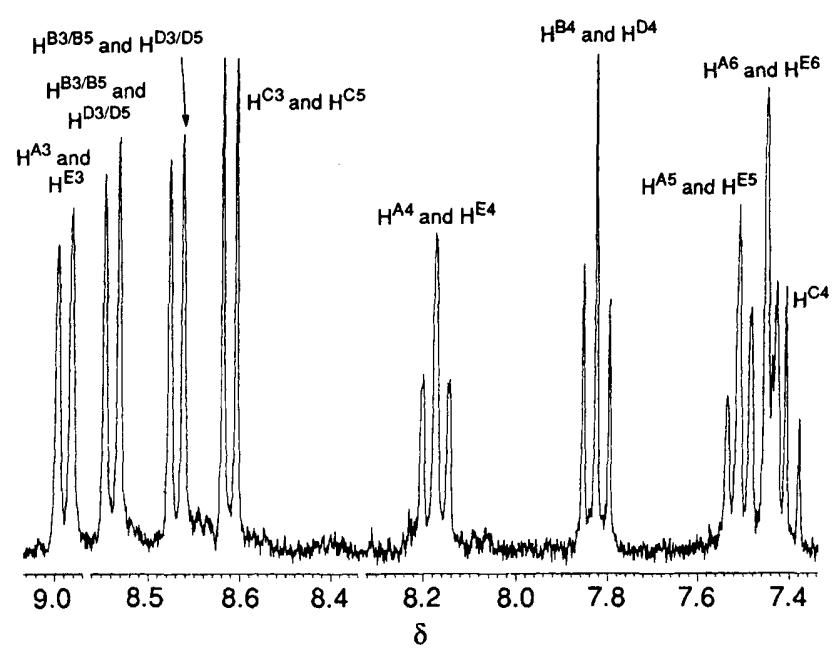

Fig. 5 Proton NMR spectrum of complex 3 in $\left(\mathrm{CD}_{3}\right)_{2} \mathrm{SO}$

ably this is due to lack of $\pi$ stacking in $\mathbf{3}$. This is good evidence that $\left[\mathrm{Re}(q p y) \mathrm{Cl}_{2}\right]^{+}$remains monomeric in solution. The molecular structure of $\mathbf{3}$ in solution has also been verified by its electrospray mass spectrum. This shows one group of peaks centred at $m / z=644$, with a virtually identical isotopic mass distribution to that calculated for the parent mass peak of $\left[\mathrm{Re}(\mathrm{qpy}) \mathrm{Cl}_{2}\right]^{+}$. This implies that 3 remains as a monomeric cation in solution. The UV/VIS spectrum exhibits two intense absorptions at $453(\varepsilon=4590)$ and $570 \mathrm{~nm}\left(\varepsilon=10010 \mathrm{dm}^{3}\right.$ $\left.\mathrm{mol}^{-1} \mathrm{~cm}^{-1}\right)$ in acetonitrile solution at room temperature. Since intense visible absorptions are also found for other rhenium(III) polypyridine complexes such as $\left[\mathrm{Re}(\mathrm{en})_{2}(\mathrm{py}) \mathrm{Cl}\right]^{+},{ }^{13}[\mathrm{Re}(\mathrm{bi}-$ py) $\left.\left(\mathrm{PPh}_{3}\right) \mathrm{Cl}_{3}\right]^{12}$ and $\left[\mathrm{Re}(\text { terpy })_{2} \mathrm{Cl}\right]^{2+},{ }^{15}$ but are absent for $\left[\mathrm{Re}^{\mathrm{III}}\left(\mathrm{PR}_{3}\right)_{3} \mathrm{X}_{3}\right],{ }^{20}$ we tentatively assign the absorption bands of 3 to the $\mathrm{d}_{n}\left(\mathrm{Re}^{\mathrm{III}}\right) \longrightarrow \pi^{*}$ (qpy) m.l.c.t. transition.

The cyclic voltammograms of complexes 2 and 3 in MeCN are shown in Fig. 6. Complex 2 displays three quasi-reversible reduction waves and a broad irreversible oxidation wave. The latter is tentatively assigned to the oxidation of $\operatorname{Re}^{\mathrm{I}}$ since the qpy ligand is electroinactive at this potential. The two reduction waves at -1.48 and $-1.73 \mathrm{~V}$ are absent for 3 , and hence they are assigned to sequential reduction of the two $\mathrm{Re}^{1}$ in the bimetallic complex 2 . If $\mathbf{2}$ behaves as two discrete $\left[\operatorname{Re}(\text { diimine })(\mathrm{CO})_{3}(\mathrm{py})\right]^{+}$there should be only one twoelectron metal-centred reduction wave. Thus a certain extent of electronic coupling, represented by the $250 \mathrm{mV}$ difference in potential between the two reduction waves, exists between the two $\mathrm{Re}^{1}$ upon reduction. In fact, the broadness of the irreversible oxidation wave could also be rationalized by (a)

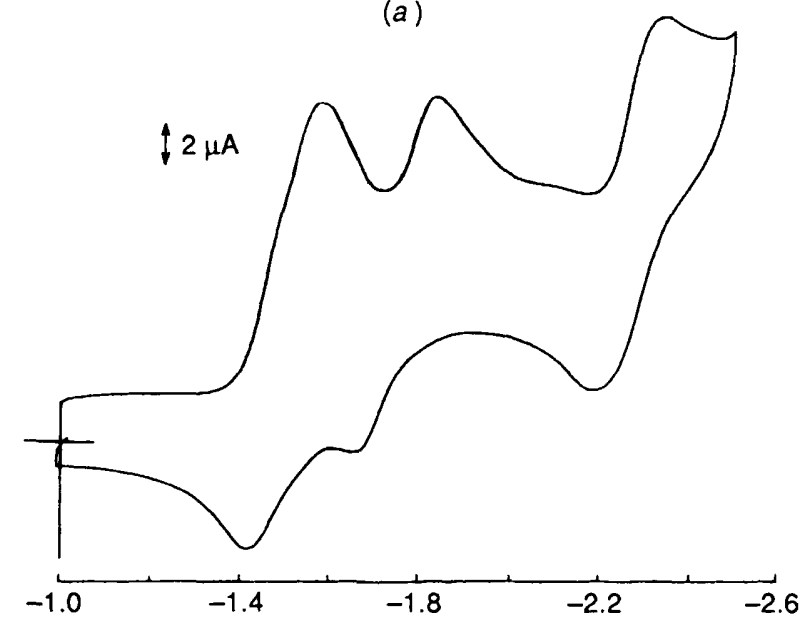

(b)

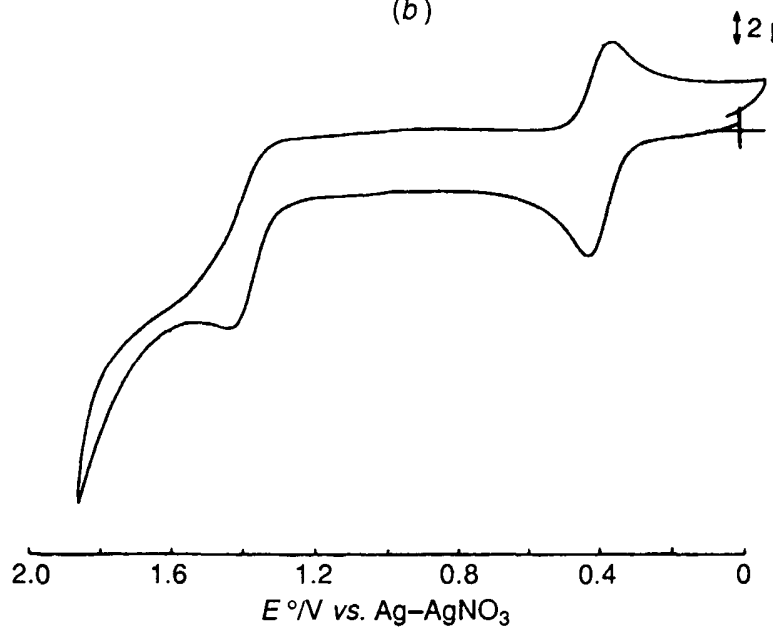

Fig. 6 Cyclic voltammograms of complexes $2(a)$ and $3(b)$

the potentials required for the oxidation of the two rhenium(I) centres, to be close to each other. Similar electrochemical behaviour has been observed for other bimetallic double-helical metal complexes. ${ }^{11}$ The remaining reduction wave at $-2.28 \mathrm{~V}$, which is also present for $\mathbf{3}$, is tentatively assigned as a ligandbased reduction. For 3 two reduction waves are found at -1.12 and $-1.25 \mathrm{~V}$. With reference to previous electrochemical studies on the related rhenium(III) complexes such as $\left[\mathrm{Re}(\text { ampy })_{2} \mathrm{Cl}_{2}\right]^{+},{ }^{13}$ the reduction waves would involve the couple $\mathrm{Re}^{\mathrm{III}}-\mathrm{Re}^{\mathrm{II}}$. There is a reversible oxidation wave with $E_{1}$ at $+0.38 \mathrm{~V}$, which is tentatively assigned to oxidation of $\mathrm{Re}^{\mathrm{i} h}$ to $\operatorname{Re}^{\mathrm{IV}}$. An additional irreversible oxidation wave was found at $+1.4 \mathrm{~V}$.

\section{Acknowledgements}

We acknowledge support from The University of Hong Kong, the Hong Kong Research Grants Council and The Croucher Foundation.

\section{References}

1 M. Wrighton and D. L. Morse, J. Am. Chem. Soc., 1974, 96, 998; M. Wrighton, Chem. Rev., 1974, 74, 4801.

2 (a) J. V. Caspar and T. J. Meyer, J. Phys. Chem., 1983, 87, 952; (b) L. A. Sacksteder, M. Lee, J. N. Demas and B. A. Degraff, J. Am. Chem. Soc., 1993, 115, 8230.

3 L. E. Helberg, J. Barrera, M. Sabat and W. D. Harman, Inorg. Chem., 1995, 34, 2033.

4 C. M. Che, Y. P. Wang, K. S. Yeung, K. Y. Wong and S. M. Peng, J. Chem. Soc, Dalton Trans, 1992, 2675.

5 (a) E. C. Constable, M. G. B. Drew and M. D. Ward, J. Chem. Soc., Chem. Commun., 1987, 1600; (b) E. C. Constable, M. G. B. Drew, G. Forsyth and M. D. Ward, J. Chem. Soc., Chem. Commun., 1988, 
1450; (c) M. Barley, E. C. Constable, S. A. Corr, R. C. S. McQueen, J. C. Nutkins, M. D. Ward and M. G. B. Drew, J. Chem. Soc. Dalton Trans., 1988, 2655; (d) E. C. Constable, M. D. Ward, M. G. B. Drew and G. A. Forsyth, Polyhedron, 1989, 8, 2551 (e) E. C. Constable, S. M. Elder, P. R. Raithby and M. D. Ward, Polyhedron, 1991, 10, 1395; $(f)$ E. C. Constable, J. V. Walker, D. A. Tocher and M. A. M. Daniels, J. Chem. Soc., Chem. Commun. 1992, 768; $(g)$ E. C. Constable, M. A. M. Daniels, M. G. B. Drew, D. A. Tocher, J. V. Walker and P. D. Wood, J. Chem. Soc., Dalton Trans., 1993, 1947; (h) E. C. Constable, S. M. Elder, J. Healy and M. D. Ward, J. Am. Chem. Soc., 1990, 112, 4590.

6 E. C. Constable and R. Chotalia, J. Chem. Soc., Chem. Commun., 1992, 64; E. C. Constable, M. J. Hannon, A. Martin and P. R. Raithby, Polyhedron, 1992, 11, 2967.

7 F. Kröhnke, Synthesis, 1976, 1

8 G. W. Parshall, Inorg. Synth., 1977, 17, 110

9 (a) TEXSAN-TEXRAY Structure Analysis Package, Molecular Structure Corporation, Houston, TX, 1985; (b) NRCVAX, E. J. Gabe, Y. Le Page, J. P. Charland, F. L. Lee and P. S. White, J. Appl. Crystallogr., 1989, 22, 384.

10 A. C. T. North, D. C. Philips and F. S. Mathews, Acta Crystallogr. Sect. A, 1968, 24, 351.
11 K. T. Potts, M. Keshavarz-K, F. S. Tham, H. D. Abruna and C. Arana, Inorg. Chem., 1993, 32, 4436.

12 J. V. Caspar, B. P. Sullivan and T. J. Meyer, Inorg. Chem., 1984, 23, 2104.

13 S. D. Orth, J. Barrera, M. Sabat and W. D. Harman, Inorg. Chem., 1993, 32, 594.

14 L. Chang, J. Rall, F. Tisato, E. Deutsch and M. J. Heeg, Inorg. Chim Acta, 1993, 205, 35.

15 J. Rall, F. Weingart, D. M. Ho, M. J. Heeg, F. Tisato and E. Deutsch, Inorg. Chem., 1994, 33, 3442.

16 G. Rouschias and G. Wilkinson, J. Chem. Soc. A, 1967, 993

17 L. Wallace, C. Woods and D. P. Rillema, Inorg. Chem., 1995, 34, 2875 .

18 (a) S. Warner and J. Lippard, Inorg. Chem., 1989, 28, 3008; (b) J.-M. Manoli, C. Potvin, J.-M. Bregeault and W. P. Griffith, J. Chem. Soc., Dalton Trans., 1979, 192.

19 J.-L. Vanderheyden, M. J. Heeg and and E. Deutsch, Inorg. Chem., $1985,24,1666$.

20 H. P. Guntz and G. P. Leigh, J. Chem. Soc. A, 1971, 2229.

Received 2nd October 1995; Paper 5/06476G 